\title{
Analysis of Ideological and Political Education Theories under the Network Environment
}

\section{Xichun Wang}

\author{
Liaoning Jianzhu Vocational College, Liaoyang, Liaoning, 111000
}

Keywords: ideological and political education theory; network environment; study and reflection

\begin{abstract}
The development of network information technology has had a tremendous and profound impact on the ideological and political education of college students. It has not only provided new opportunities and development for ideological and political education of college students, but also brought a series of problems and challenges. Starting from the importance of ideological and political education in the Internet environment, this paper proposes innovative ideas, content, methods, ways and ideas and methods for ideological and political education in an Internet environment based on an objective analysis of the current situation.
\end{abstract}

\section{Introduction}

Today's social network information technology is highly developed, along with the co-existence of network information. In carrying out ideological and political education, colleges and universities not only face the content of ideological and political education, but also need to consider the methods of ideological and political education, how to use effective and advanced network information technology to improve the level of ideological and political education in universities, and how to strengthen the network The reform of the ideological and political education methods in the age of information technology to help college students form healthy and positive values in life are problems that universities must consider. At present, college students have weaker ability to judge and process complex information, and they lack certain judgments on some ideological and political contents on the Internet [1]. Therefore, colleges and universities in the process of strengthening the network of ideological and political education need to properly guide the students' ideas, so as to effectively improve the quality of ideological and political education.

\section{Status Quo of Ideological and Political Education in Network Environment}

The cyber society is a social place formed by the interaction of netizens in the virtual space. Under normal circumstances, network society is a network virtual space formed by some Internet users with the same or similar hobbies through WeChat, QQ and other network exchange platforms. At present, the Internet is not only an important tool to meet the needs of college students in terms of learning, examinations, job search, and entrepreneurship, but also provides a virtual platform for college students to communicate and learn to release pressure. The rapid development of the Internet has suddenly become a survival mode for the informatization of a new generation of college students. According to the relevant literature and website search, there are only a few literatures on the ideological and political work of college students in the network environment. Most of them mainly focus on the impact of the Internet on college students' thoughts and behaviors, and a small part of them explore the ideological and political education under the network environment [2]. The idea, but lack of operability and reproducibility. Most of the current ideological and political education on the Internet involves moving books directly to the Internet. From this we can see that there are too few educational methods suited to the characteristics of the development of the Internet. It is still far from the "standards of ideological and political education must be diversified and the content of education must be flexible and diverse" proposed by the Ministry of Education. With the popularization and development of the Internet in our country, the information transmitted by the Internet has had a profound impact on the study, life and ideology of 
college students, and it has also brought new opportunities and severe challenges to ideological and political education in universities. How to deal with the impact of the Internet on college students and ideological and political education Colleges, and strengthen the ideological and political education Colleges under the network environment is an important issue facing the ideological and political education Colleges in the new era.

\section{The Challenge of Ideological and Political Education in the Network Environment}

With the rapid development of computer network technology, the high school campus has become the most densely integrated region in China. The information transmitted by the Internet has also exerted increasingly profound influence on university students' political thoughts, feelings, quality, and mentality [3]. Mainly reflected in two aspects. First, it has brought challenges to the formation of the world outlook, outlook on life, and values of college students. In the past, people accepted information through broadcasting, television, and other media. Their contents were reviewed and screened, and the arrival of the Internet society. Break this stable pattern. The Internet is an open world. Information on the Internet is uneven, and the disorderly nature of cultural transmission under network conditions will affect the normal growth of university students. Some college students still lack the correct ability to discriminate between right and wrong, and bad information on the Internet can easily cause confusion in their thinking. This is not conducive to their formation of a correct, scientific outlook on the world, outlook on human life and values.

Second, it poses a challenge to the development of physical and mental health of college students. The essence and dross of network information coexist. For some college students who lack self-control, this information not only poisons their hearts, but also weakens their morality. Legal consciousness and the virtualized way of using their will to spread the Internet have had a profound impact on college students' communication methods and interpersonal relationships. They have led to the tendency of their behavioral bodies to be indifferent. The occult nature of networks has brought opportunities for ideological and political education. At the same time it also brings hidden dangers. Some students saw the characteristic of publishing anonymous information on the Internet, randomly issuing various kinds of false information, slandering or retaliating against others through the Internet, and some even went to the depth of crime. The challenge brought to the ideological and political education content of colleges and universities in the Internet is how to make simple college students avoid absorbing unhealthy content and not be affected by spam, and how to make the contents of college ideological and political education favorite by college students. Adapting to the requirements of college students' thoughts and conditions in the cyber era is a great challenge to the content of ideological and political education Colleges.

\section{New Features and Innovations of Ideological and Political Education in the Network Environment}

Under the background of the rapid development of the Internet, colleges and universities in our country have formed a variety of ideological and political education models. Under the extremely complex social network environment at this stage, the ideological and political education work in universities in China is full of opportunities, but it will also face many unfavorable factors. How to solve the problem of ideological and political education in the network environment in a timely manner and guide students Colleges to form healthy and positive life values has become an urgent problem that universities need to solve [4]. The innovation of ideological and political education Colleges should be changed from prohibition to grooming, from closure to openness, from single means to full-scale management, and from exchangeable to interactive.

The ideological and political education Colleges emphasizes that the school is the organizational unit, and in a certain period of time, through the planned and organized guidance of the school, students are allowed to subconsciously improve their self-cultivation. This teaching method is not only in line with the needs of the students' own development, but also in line with the ideological concepts and character behaviors of the contemporary historical period. With the rapid development 
of electronic information technology, colleges and universities began to combine ideological and political education with electronic information technology. According to the development of the overall quality of students, it is necessary to carry out ideological and political education. The development of a new model of network ideological and political education facilitates students to understand and master ideological and political theoretical knowledge more profoundly, and at the same time make the content of ideological and political education Colleges more vivid.

The use of the Internet to strengthen ideological and political education Colleges has an interactive advantage over traditional education methods. The subject and object of education can be more freely and flexibly interacted with each other in a two-way way, enabling timely communication and understanding. The ideological and political education, which takes the Internet as the main transmission route, through the interaction on the Internet, completes the message spread between the subject idea of the educational object thought and educational practice activity. The traditional ideological education model pays more attention to the spread of educational ideology and theory, ignoring the interaction between subject and object. The ideological and political education under the network environment can just make up for this shortcoming, and begins with a one-way communication of educational thoughts to two-way modes. Interactive mode changes. In such a good atmosphere of two-way interaction, the students can communicate and communicate with the teachers adequately, and also enhance the autonomy of the study. This has a multiplier effect for the teaching effect of the entire course. At the same time, the mode of ideological and political education is more three-dimensional, allowing students to acquire resources related to ideology and politics in a timely and efficient manner while fully acquiring network resources. It is particularly worth mentioning that students interact with teachers through mutual refutation and discussion, and both parties can correct their own deficiencies in a timely manner so as to enhance their respective ideological and political theories [5].

Compared with the traditional ideological and political education under the network environment, the ideological and political education may need to be reflected after a longer period of time, that is, the cycle is longer. This is due to the fact that under the online education model, students mainly learn through subtle influences on massive information resources. In this process of interaction with teachers, its teaching activities are mainly carried out by both sides through subtle activities. It is different from traditional indoctrinative ideological and political education modes, effectively avoiding the positive friction between students and teachers. The student's resistance was reduced and the ideological and political education activities were better completed. From this point of view, networked teaching has lasting and long-term effects and is more in line with the acceptance of students.

At the same time as the rapid development of Internet construction and network information technology in China, the coverage of the Internet is also growing, and online education has also grown. Because of the characteristics of network information technology, online education that coexists with it has also become more open. Utilizing the openness of the network, college teachers and students can quickly and quickly obtain more complete and detailed ideological and political theory updates and research results in a relatively short period of time, so as to realize the collection, analysis, and sharing of current research results. At the same time, students can also timely exchange questions and experiences with teachers according to their own learning progress, solve their problems and confusion in real learning in time, and better master ideological and political theories. Such an education model directly breaks the obstacles in communication between time and space and promotes teacher-student communication. With the rapid development of the Internet, students can better find the resources they need through the Internet, which not only enriches network resources, but also improves the quality of network resources. Using the sharing platform of the Internet, information sharing between universities and colleges can be achieved, and all colleges and universities can learn from and learn from other schools' excellent teaching experience and theoretical results, so that more colleges and universities can smoothly realize the ideological and political education model innovation.

In order to ensure the quality of ideological and political education and optimize the ideological 
and political education, colleges and universities need to explore new ways and methods of ideological and political education that match their own characteristics in light of their actual development. With the rapid development of the information age, the means and methods of education Colleges can make greater use of modern communication media and break the traditional way of education with board-based education as the main means of education. Combining ideological and political education with multimedia sound, video, and drawing to achieve three-dimensional teaching. Colleges and universities can also use the Internet platform to build ideological and political posts and forums. They can also establish forums and communities for network exchanges, and continuously increase the proportion of online education in ideological and political education in universities, and maximize the effectiveness of Internet teaching. For some qualified colleges and universities, even a new teaching class can be opened, new teaching equipment can be added, and a diversified and open teaching system can be established as soon as possible.

\section{Conclusion}

Online education has not only broadened the teaching methods and modes of ideological and political education in China's universities, but also increased its openness and interactivity. It has also broadened the educational space for political ideology in Chinese universities. Network information technology brings convenience to the study of college students. At the same time, it also poses new challenges to the innovation of ideological and political education Colleges. Therefore, Chinese universities must strive to conform to the development of the times, use contemporary information technology, and effectively improve the level of ideological and political education Colleges.

\section{References}

[1] Li Ping. Exploration of innovative ways of undergraduates' ideological and political education under the Internet environment [J]. Lanzhou Pedagogy Journal of Chinese Academy of Sciences, 2012(7):144-145.

[2] Zhou Zhiqiang. Thinking on Constructing Network Ideological and Political Education System[J]. Journal of Southwest University, 2012(24):52-54.

[3] Yuan Lin, Li Meiqing. Research on the Dilemma and Solution of the Process of Network Propagation in Ideological and Political Education [J]. Ideological and Theoretical Education Guide, 2010(6):80-84.

[4] Jin Jiankang, et al. Ideological and political education[M]. Beijing: Hydraulic and Electric Power Publishing Society, 1987.

[5] Zhang Yaocan. Principles of ideological and political education[M]. Wuhan: Huazhong Normal University Academic Press, 1988. 